\title{
PENGGUNAAN GARAM BERYODIUM DAN ASUPAN PROTEIN TERHADAP PENCAPAIAN PRESTASI MURID SDN 5 KOTA BANDA ACEH
}

\author{
Agus Hendra AL-Rahmad \\ ${ }^{1}$ Jurusan Gizi, Politeknik Kesehatan Kemenkes Aceh, J1. Soekarno Hatta, Kampus Terpadu Poltekkes Kemenkes RI \\ Aceh Lampeneurut, Aceh Besar. Telp.065146126. email: 4605.ah@gmail.com
}

\begin{abstract}
ABSTRAK
Rendahnya asupan zat gizi mengakibatkan kehilangan tingkat kecerdasan anak yang berpengaruh terhadap prestasi belajar anak. Provinsi Aceh, rata-rata anak usia sekolah dasar mengkonsumsi protein diatas kecukupan konsumsi protein perkapita (90-110\% AKG). Kota Banda Aceh, pencapaian indikator kinerja pembinaan gizi, rumah tangga yang mengkonsumsi garam beryodium masih kurang yaitu hanya 48,7\%. Tujuan penelitian yaitu untuk mengukur hubungan penggunaan garam beryodium dan asupan protein terhadap prestasi belajar pada murid sekolah dasar. Penelitian kuantitatif dengan rancangannya adalah Crossectional. Variabel penelitian terdiri dari penggunaan garam beryodium dan asupan protein. Data dikumpulkan dengan cara wawancara dan observasi. Analisa data menggunakan uji statistik regresi linier pada CI 95\%. Hasil statistik, tidak ada hubungan penggunaan garam beryodium terhadap prestasi belajar $P=0,073$ dimana $(p>0,05)$. Ada hubungan asupan protein terhadap prestasi belajar $P=0,004$ dimana ( $p<0,05)$. Penggunaan garam beryodium tidak menunjukan hubungan terhadap prestasi belajar, sedangkan asupan protein mempunyai hubungan signifikan terhadap prestasi belajar. Untuk meningkatkan kemampuan pikir anak, sebaiknya diberikan cukup protein dan selalu menggunakan garam yang mengandung yodium
\end{abstract}

Kata Kunci : Garam Beryodium, Asupan Protein, Prestasi Belajar

\begin{abstract}
Low intake of nutrients resulting in loss of the child's intelligence level that affect the learning achievement of children. Aceh province, the average primary school age children consume adequate protein on protein consumption per capita (90-110\% RDA). Banda Aceh, based on the achievement of performance indicators report nutritional coaching, households consuming iodized salt is still lacking is only 48.7\%. The purpose of research is to measure the relative use of iodized salt and protein intake on learning achievement in elementary school students. Quantitative study design was crosssectional. The variables consisted of the use of iodized salt and protein intake. Data were collected by interview and observation. Data were analyzed using linear regression statistical test on the $95 \%$ CI. Statistical results, there was no association of use of iodized salt on learning
\end{abstract}

achievement $P=0.073$ where $(p>0.05)$. There is a relationship of protein intake on learning achievement $P$ $=0.004$ where $(p<0.05)$. The use of iodized salt showed no relationship to the learning achievement, while protein intake had no significant relationship to the student achievement.

Key words : Iodized salt, Protein intake, Learning achievement

\section{PENDAHULUAN}

Secara statistik dan kependudukan di Indonesia umur 6 hingga 12 tahun digolongkan usia sekolah dasar. Selama usia sekolah dasar, pertumbuhan tetap terjadi walau tidak dengan kecepatan pertumbuhan sehebat yang terjadi sebelumnya pada masa bayi atau masa remaja nantinya. Anak-anak pada periode usia ini tetap mempunyai dorongan pertumbuhan yang biasanya bertepatan dengan periode peningkatan asupan makan. Ketika memasuki periode pertumbuhan yang lebih lambat, asupan makan seorang anak juga berkurang ${ }^{[1]}$. Tahun sekolah dasar awal merupakan waktu untuk menggunakan dan menguji keterampilan dari motorik yang berkembang ${ }^{[2]}$.

Anak usia sekolah adalah investasi bangsa, karena anak usia tersebut adalah generasi penerus bangsa. Pertumbuhan anak usia sekolah yang optimal tergantung pemberian asupan dan penggunaan jenis makanan dengan kualitas dan kuantitas yang benar. Dalam masa pertumbuhan tersebut pemberian asupan makanan pada anak tidak selalu dapat dilaksanakan dengan sempurna $^{[3]}$.

Proses belajar mengajar adalah kegiatan utama dalam dunia pendidikan di sekolah. Penentuan keberhasilan proses belajar mengajar di sekolah banyak melibatkan beberapa faktor atau komponen yang mendukung. Keberhasilan tersebut dapat diukur melalui kegiatan evaluasi 
belajar yang merupakan salah satu faktor penentu prestasi belajar siswa ${ }^{[3]}$.

Angka Partisipasi Sekolah (APS) di Indonesia pada tahun 2010 usia 11 tahun yaitu sebanyak 98,02\%. Tingkat penduduk Aceh berusia sekolah yang memanfaatkan fasilitas pendidikan baik pada tingkat SD, SLTP, maupun SLTA sederajat meningkat pada tahun 2010 dan lebih tinggi daripada rata-rata angka Indonesia. Pada kelompok usia 7-12 tahun, mencapai $99,19 \%$ yang berarti hanya $1 \%$ penduduk usia $7-$ 12 tahun yang tidak bersekolah SD sederajat. Pencapaian APS tersebut telah mengungguli capaian rata-rata APS secara nasional. Seiring dengan hal itu terdapat penurunan persentase penduduk 10 tahun keatas yang hanya mempunyai ijazah SD sederajat menjadi $26,18 \%$ dan tidak atau belum tamat SD menjadi $21,68 \%{ }^{[4]}$.

Kondisi output pendidikan dapat dilihat dari persentase penduduk Aceh yang mampu membaca dan menulis. Angka Melek Huruf (AMH) penduduk aceh terus mengalami peningkatan dari $96,39 \%$ menjadi $96,88 \%$ selama 2009-2010 dan pada tahun 2011 meningkat lagi menjadi yaitu 96,95\%. Angka ini telah melebihi capaian angka melek huruf Indonesia sebesar $92,99 \%$. Selain daripada itu, output pendidikan Aceh tercermin dari persentase penduduk berusia 10 tahun ke atas menurut ijazah tertinggi yang dimiliki. Secara umum, proporsi masyarakat Aceh yang memiliki ijazah dengan tingkat pendidikan dasar kebawah lebih tinggi. Hal ini ditunjukkan dari 20,31\% tidak memiliki atau belum memiliki ijazah SD. Di tingkat lebih tinggi, sebesar 48,87\% hanya memiliki ijazah pendidikan dasar yaitu SD sederajat $27,55 \%^{[4]}$.

Salah satu upaya yang dapat dilakukan untuk mempertinggi kualitas anak Indonesia pada kelompok anak sekolah dasar adalah dengan cara meningkatkan kualitas dan kuantitas makanan yang dikonsumsi sehari-hari. Keberadaan penyakit Gangguan Akibat Kekurangan Iodium (GAKI) dinilai melalui inspeksi dan palpasi serta insentitas penyakitnya diklasifikasikan menurut ukuran kelenjar gondok tersebut. Menurut WHO, 13\% populasi penduduk dunia sudah terkena GAKI dan 30\% lainnya beresiko. Hampir 50 juta penduduk diyakini sudah menderita bentuk tertentu kelainan neurologi atau gangguan kognitif yang berkaitan dengan $\mathrm{GAKI}^{[5]}$.

Di Indonesia, rata-rata anak usia sekolah dasar mengkonsumsi protein yaitu $113,2 \%$ atau berada diatas kecukupan konsumsi protein perkapita (90-110\% AKG). Konsumsi protein di Indonesia saat ini lebih baik karena sudah di atas batas ambang normal sedangkan anak yang mengkonsumsi protein dibawah 80\% dari Angka Kecukupan Gizi (AKG) hanya menunjukkan rata-rata sebesar 30,6\% (Riskesdas, 2010). Secara nasional konsumsi garam mengandung yodium cukup ( $\geq 30 \mathrm{ppm}$ ) hanya $62,3 \%$. Provinsi Aceh, rata-rata anak usia sekolah dasar mengkonsumsi protein yaitu $129,1 \%$ atau berada diatas kecukupan konsumsi protein perkapita (90-110\% AKG). Konsumsi protein di Aceh saat ini lebih baik karena sudah di atas batas ambang normal sedangkan anak yang mengkonsumsi protein dibawah $80 \%$ dari Angka Kecukupan Gizi (AKG) hanya menunjukkan rata-rata sebesar 19,3\%[6].

Kota Banda Aceh, berdasarkan laporan pencapaian indikator kinerja pembinaan gizi, rumah tangga yang mengkonsumsi garam beryodium masih kurang yaitu hanya $48,7 \%{ }^{[7]}$. Hasil penelitian menunjukkan $75 \%$ dari $30 \%$ siswa SD/MI yang menderita kretin mengalami kesulitan belajar disekolah, sehingga mereka memerlukan perhatian dan pelayanan tertentu agar tidak gagal dalam pendidikan. Gangguan Akibat Kekurangan Iodium (GAKI) merupakan salah satu masalah gizi yang menjadi faktor penghambat pembangunan sumber daya manusia karena dapat menyebabkan terganggunya perkembangan mental dan kecerdasan terutama pada anak-anak. Gangguan tersebut dapat berakibat pada rendahnya prestasi belajar anak usia sekolah. Tim GAKY Pusat tahun 2005 menyebutkan dari sejumlah 20 juta penduduk Indonesia yang menderita GAKY diperkirakan dapat kehilangan 140 juta angka kecerdasan atau IQ points ${ }^{[8]}$.

Kebutuhan gizi yang berperan dalam prestasi belajar anak secara garis besar mencakup kebutuhan akan asupan protein dan mineral. Salah satu mineral yang penting di dalam laju perkembangan anak adalah penggunaan garam beryodium. Nutrisi atau zat 
gizi seperti asupan protein dan penggunaan garam beryodium harus cukup karena kekurangan kadar makanan ini akan mengakibatkan kehilangan point IQ atau tingkat kecerdasan anak yang berpengaruh terhadap prestasi belajar anak. Tujuan penelitian secara umum yaitu untuk mengukur hubungan penggunaan garam beryodium dan asupan protein terhadap prestasi belajar pada murid kelas V SD Negeri 5 Kota Banda Aceh.

\section{DESAIN PENELITIAN}

Penelitian ini merupakan penelitian kuantitatif yang menggunakan desain Crossectional Study ${ }^{[10]}$, yang dilaksanakan pada Sekolah Dasar Negeri 5 Kota Banda Aceh, pada tanggal $05-24$ Juli 2015. Populasi penelitian seluruh murid yang berjumlah sebanyak 62 siswa. Besar sampel menggunakan rumus ukuran sampel untuk menguji hipotesis satu sisi pada proporsi satu populasi yaitu Slovin, hasil perhitungannya yaitu diperoleh sebanyak 34 siswa. Mempertimbangkan kesesuaian dengan jumlah kelompok data yang ada, maka sampel yang telah terpilih merupakan hasil Stratifield Random Sampling.

Penelitian menggunakan dua jenis data yang dikumpulkan yaitu data primer dan data sekunder. Data primer terdiri data karakteristik responden, data asupan protein, penggunaan garam beryodium, dan prestasi belajar. Data primer ini dikumpulkan secara wawancara secara langsung menggunakan kuesioner, melakukan food recall 24 jam, penggunaan iodine tes serta melakukan observasi nilai rapor . Sedangkan data sekunder dilakukan secara observasi sebagai metode pengumpulan data dilaksanakan dengan cara mengamati langsung jalan tertentu disertai pendataan.

Pengolahan data penelitian meliputi empat tahapannya yaitu tahap editing, coding, cleaning sampai tahap data entry. Analisis data baik secara univariat maupun bivariat menggunakan software komputer. Dalam menjawab tujuan penelitian serta membuktikan hipotesis, digunakan analisis uji statistik yaitu Chi-Square dengan tingkat kemaknaan $95 \%^{[11]}$. Hasil penelitian disajikan dalam bentuk tekstular dan tabular.

\section{HASIL DAN PEMBAHASAN}

Sekolah Dasar Negeri 5 Banda Aceh berdiri pada tahun 1950. Berdiri di atas sebidang tanah wakaf seluas $\pm 3.314 \mathrm{~m}^{2}$. Sekolah Dasar Negeri 5 Banda Aceh berada di Jl. STA Johansyah Desa Seutui Kecamatan Baiturrahman Kota Banda Aceh, Provinsi Aceh. Letak SD Negeri 5 sangat strategis yang berada di jalan yang setiap waktu dilalui oleh bermacam suku bangsa di dunia yang datang berkunjung ke Aceh. SD Negeri 5 telah memiliki akreditasi sekolah yaitu A dengan jumlah siswa sebanyak 405 orang, dengan jumlah siswa laki-laki 198 dan perempuan 207 siswa. SD Negeri 5 bertempat di gedung sendiri dengan jumlah ruangan sebanyak 12 ruang kelas. Sarana prasarana yang terdapat di SD ini adalah ruang belajar, ruang guru, pustaka, wc, ruang keterampilan, kantin, rumah pesuruh dan sumur.

Sampel penelitian merupakan murid SD yang terpilih secara random sebanyak 34 siswa. Berikut ini merupakan karakteristik sampel menurut umur dan jenis kelamin, sebagaimana disajikan pada tabel 1 berikut ini.

\section{Tabel 1. Distribusi Karakteristik Sampel Menurut Umur dan Jenis Kelamin}

\begin{tabular}{lcc}
\hline \multicolumn{1}{c}{$\begin{array}{c}\text { Karakteristik } \\
\text { Sampel }\end{array}$} & $\mathrm{n}$ & $\%$ \\
\hline Umur & & \\
- 10 Tahun & 23 & 67,7 \\
- 11 Tahun & 11 & 32,3 \\
\hline Jenis Kelamin & & \\
- Laki-Laki & 21 & 61,8 \\
- Perempuan & 13 & 38,2 \\
\hline \multicolumn{1}{c}{ Jumlah } & 34 & 100,0 \\
\hline
\end{tabular}

Dari tabel di atas diketahui bahwa karakteristik sampel di SD 5 Negeri Kota Banda Aceh menurut umur pada umumnya yaitu berumur 10 tahun yaitu sebesar $67,7 \%$ dan karakteristik jenis kelamin pada umumnya lakilaki yaitu sebesar $61,8 \%$.

Selanjutnya gambaran terhadap hasil penelitian secara variabelitas disajikan pada tabel 2 untuk memberikan gambaran secara deskriptif yang memuat asupan protein dan penggunaan garam beryodium (variabel independen) serta prestasi belajar (variabel 
dependen) pada subjek penelitian di SD Negeri 5 Kota Banda Aceh.

Tabel 2. Distribusi Frekuensi Variabel Independen dan Variabel Dependen Di SDN 5 Kota Banda Aceh $(n=34)$

\begin{tabular}{lcc}
\hline \multicolumn{1}{c}{ Variabel Penelitian } & $\mathrm{n}$ & $\%$ \\
\hline Asupan Protein & 6 & 17,6 \\
- Lebih & 12 & 35,3 \\
- Cukup & 16 & 47,1 \\
- Kurang & 17 & 50,0 \\
\hline Garam Beryodium & 17 & 50,0 \\
- Positif & & \\
- Negatif & 12 & 35,3 \\
Prestasi Belajar & 22 & 44,7 \\
- Sangat Baik & & \\
- Baik &
\end{tabular}

Berdasarkan hasil penelitian (tabel 2) terlihat bahwa tingkat asupan protein siswa di SD Negeri 5 Kota Banda Aceh lebih banyak yang mempunyai asupan kurang $(<80 \%$ AKG $)$ yaitu sebesar 47,1\%. Sedangkan untuk penggunaan garam beryodium, masing-masing hasil iodine test menunjukan sebesar 50,0\% garam yang dibawa siswa yaitu mengandung iodium (positif) sedang $50,0 \%$ lainnya merupakan garam yang tidak mengandung iodium (negatif).

Prestasi belajar merupakan variabel dependen dalam penelitian ini. Pengukuran prestasi belajar mengacu kepada hasil rata-rata nilai rapor siswa, dengan batasan sebagai berikut yaitu sangat baik (rerata nilai rapor 81-100), baik (rerata nilai rapor 66-80), cukup (rerata nilai rapor 51-65), dan kurang (rerata nilai rapor 0 50). Hasil penelitian terhadap prestasi belajar siswa di SD Negeri 5 Kota Banda Aceh menunjukan sebesar $44,7 \%$ mempunyai prestasi yang baik dan sebesar $35,3 \%$ prestasi siswa sangat baik. Hal ini memberikan gambaran bahwa pencapaian prestasi siswa sudah memenuhi standar kelulusan yang baik di SD Negeri 5 Kota Banda Aceh.

Hubungan antara tingkat asupan protein dengan prestasi belajar pada siswa di SD Negeri 5 Kota Banda Aceh yanh dianalis secara uji statistik Chi-Square dengan CI:95\% secara komputerisasi dan hasilnya disajikan pada tabel 3 berikut ini :

\section{Tabel 3. Hubungan Tingkat Asupan Protein dengan Prestasi Belajar Siswa di SD Negeri 5 Kota Banda Aceh}

\begin{tabular}{|c|c|c|c|c|c|c|c|}
\hline \multirow{3}{*}{$\begin{array}{c}\text { Tingkat Asupan } \\
\text { Protein }\end{array}$} & \multicolumn{4}{|c|}{ Prestasi Belajar } & \multirow{2}{*}{\multicolumn{2}{|c|}{ Total }} & \multirow{3}{*}{ P-Value } \\
\hline & \multicolumn{2}{|c|}{ Sangat Baik } & \multicolumn{2}{|c|}{ Baik } & & & \\
\hline & $\mathrm{n}$ & $\%$ & $\mathrm{n}$ & $\%$ & $\mathrm{n}$ & $\%$ & \\
\hline Lebih & 4 & 66,7 & 2 & 33,3 & 6 & 100,0 & $0,004 *$ \\
\hline Cukup & 7 & 58,3 & 5 & 41,7 & 12 & 100,0 & \\
\hline Kurang & 1 & 6,2 & 15 & 93,8 & 16 & 100,0 & \\
\hline Total & 12 & 35,3 & 22 & 62,7 & 34 & 100,0 & \\
\hline
\end{tabular}

*) Signifikan pada CI:95\%

Berdasarkan tabel 7, diketahui murid yang asupan proteinnya lebih sebesar $66,7 \%$ prestasi belajarnya yaitu sangat baik, murid yang asupan proteinnya cukup sebesar $58,3 \%$ prestasi belajarnya sangat baik, dan murid yang asupan proteinnya kurang sebesar $93,8 \%$ prestasi belajarnya yaitu baik. Hasil uji statistik di peroleh nilai probabilitas ( $p$-value) yaitu 0,004 (p $<0,05)$, hal ini berarti pada CI-95\% Ho ditolak dan Ha diterima. Kesimpulannya adalah ada hubungan yang bermakna antara asupan protein dengan prestasi belajar pada murid kelas V SD Negeri 5 Banda Aceh.

Hasil penelitian menunjukkan ada hubungan antara asupan protein dengan prestasi belajar, dimana diperoleh $\mathrm{p}<0,05$. Hal ini sejalan dengan penelitian yang dilakukan peneliti di sebuah sekolah dasar menyatakan ada hubungan yang signifikan antara asupan protein dengan prestasi belajar anak sekolah dasar ${ }^{[12]}$.

Penelitian serupa juga dilakukan oleh Roslaini bahwa terdapat hubungan yang 
bermakna antara kebiasaan konsumsi susu dengan prestasi belajar anak. Jumlah protein yang dianjurkan oleh Widya Karya Nasional Pangan dan Gizi tahun 2004 bagi Anak Usia Sekolah yang berumur $10-12$ tahun yaitu sebanyak $50 \mathrm{gr}^{[12]}$. Protein dapat ditemukan baik dalam sumber nabati maupun hewani. Dalam setiap kelompok makanan bahan makanan hewani merupakan sumber protein hewani yang baik, dalam jumlah maupun mutu seperti telur, susu, daging, unggas, ikan, dan kerang. Sumber protein nabati adalah kacang kedelai dan hasilnya, seperti tempe dan tahu, seperti kacang-

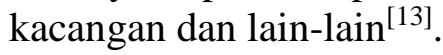

Kurang Energi Protein (KEP) adalah suatu kondisi dimana jumlah asupan zat gizi yaitu energi dan protein kurang dari yang dibutuhkan. Akibat buruk dari KEP bagi anak sekolah dasar adalah anak menjadi lemah daya tahan tubuhnya dan terjadi penurunan konsentrasi belajar. Untuk mendukung prestasi yang maksimal, kita butuh makanan yang mengandung zat gizi yang cukup seperti protein. Siswa yang perkembangan otaknya maksimal karena zat gizi yang dikonsumsi akan memiliki prestasi yang lebih maksimal dibandingkan siswa yang perkembangan otaknya kurang maksimal ${ }^{[13]}$.

Kurang zat gizi seperti asupan protein akan menyebabkan kegagalan pertumbuhan fisik dan perkembangan kecerdasan, menurunkan daya tahan tubuh, meningkatkan kesakitan dan kematian. Dalam Widyakarya Nasional Pangan dan Gizi (2000) disebutkan bahwa pada anak usia sekolah kekurangan asupan akan mengakibatkan anak menjadi lemah, cepat lelah dan sakit-sakitan sehingga anak seringkali absen serta mengalami kesulitan mengikuti dan memahami pelajaran. Selain itu anak menjadi lemah daya tahan tubuhnya dan terjadi penurunan konsentrasi belajar ${ }^{[12]}$.

Berbagai macam asupan protein mengandung zat gizi yang dibutuhkan oleh otak, yaitu ikan salmon yang bersumber dari asam lemak omega-3 DHA dan EPA yang keduanya penting bagi pertumbuhan dan perkembangan fungsi otak, kuning telur yang padat kandungan kolin (zat yang membantu perkembangan daya ingat), kacang tanah yang merupakan sumber vitamin $\mathrm{E}$ berfungsi membantu otak dan system saraf dalam penggunaan glukosa untuk kebutuhan energi, susu dan yoghurt mengandung protein dan vitamin B tinggi sangat penting untuk pertumbuhan jaringan tak dan enzim, daging sapi tanpa lemak dapat memelihara daya ingat dan kecerdasan anak ${ }^{[14]}$.

Hasil penelitian terkait dengan hubungan antara Penggunaan Garam Beryodium dengan Prestasi Belajar di di SD Negeri 5 Kota Banda Aceh sebagaimana disajikan pada tabel 4 diketahui ibu-ibu yang menggunakan garam beryodium (positif) sebesar $52,9 \%$ prestasi belajar anaknya adalah sangat baik. Ibu-ibu yang tidak menggunakan garam beryodium (negatif) sebesar $82,4 \%$ prestasi belajar anaknya yaitu baik. Hasil uji statistik di peroleh nilai probabilitas (p) yaitu 0,073 (p > $0,05)$, hal ini berarti pada CI-95\% Ho diterima dan Ha ditolak. Kesimpulannya adalah tidak ada hubungan yang bermakna antara penggunaan garam beryodium dengan prestasi belajar pada murid kelas V SD Negeri 5 Kota Banda Aceh.

\section{Tabel 4. Hubungan Penggunaan Garam Beryodium dengan Prestasi Belajar Siswa di SD Negeri 5 Kota Banda Aceh}

\begin{tabular}{|c|c|c|c|c|c|c|c|}
\hline \multirow{3}{*}{$\begin{array}{l}\text { Penggunaan Garam } \\
\text { Beryodium }\end{array}$} & \multicolumn{4}{|c|}{ Prestasi Belajar } & \multirow{2}{*}{\multicolumn{2}{|c|}{ Total }} & \multirow{3}{*}{ P-Value } \\
\hline & \multicolumn{2}{|c|}{ Sangat Baik } & \multicolumn{2}{|c|}{ Baik } & & & \\
\hline & $\mathrm{n}$ & $\%$ & $\mathrm{n}$ & $\%$ & $\mathrm{n}$ & $\%$ & \\
\hline Positif & 9 & 52,9 & 8 & 47,1 & 17 & 100,0 & 0,073 \\
\hline Negatif & 3 & 17,6 & 14 & 82,4 & 17 & 100,0 & \\
\hline Tota 1 & 12 & 35,3 & 22 & 62,7 & 34 & 100,0 & \\
\hline
\end{tabular}


Hasil penelitian ini sejalan dengan penelitian yang dilakukan oleh Mutalazimah (2009), yang berjudul "Status Yodium dan Fungsi Kognitif Anak Sekolah Dasar Di SDN Kiyaran 1 Kecamatan Cangkringan Kabupaten Sleman" yang menunjukkan bahwa tidak ditemukan hubungan antara status yodium dan fungsi kognitif anak sekolah dasar $(p=0,366)^{[8]}$.

Dari hasil penelitian menunjukkan bahwa masih terdapat ibu-ibu yang tidak menggunakan garam beryodium. Rata-rata garam yang digunakan ibu-ibu ialah garam yang tidak berlabel yodium, sebagian ibu-ibu juga mengkonsumsi garam yang berlabel yodium seperti merk dolpin, merk samudra dan lainnya. Hal ini sejalan dengan penelitian Sari (2011), yang berjudul "Faktor-Faktor Yang Berhubungan Dengan Penggunaan Garam Beryodium Di Rumah Tangga Di Kelurahan Ulak Karang Selatan Kota Padang”, yang menyatakan ada hubungan pengetahuan ibu dengan penggunaan garam beryodium di rumah tangga. Oleh karena itu, diharapkan ibu -ibu untuk dapat meningkatkan pengetahuan lebih baik lagi tentang penggunaan garam beryodium di rumah tangga, sehingga dengan meningkatnya pengetahuan ibu akan meningkatkan juga kesadaran ibu-ibu untuk menggunakan garam beryodium di rumah tangga mereka ${ }^{[4]}$.

Kelompok masyarakat yang sangat rawan terhadap masalah dampak defisiensi yodium adalah anak usia sekolah. Gangguan Akibat Kekurangan Yodium (GAKY) adalah sekumpulan gejala yang ditimbulkan karena tubuh kekurangan yodium dalam jangka waktu yang lama. GAKY ini merupakan salah satu masalah gizi utama di Indonesia. GAKY diketahui mempunyai kaitan yang erat dengan gangguan perkembangan mental dan kecerdasan. Oleh karena itu, semakin besar angka prevalensi masalah GAKY, akan semakin menurunkan prestasi belajar anak dikarenakan kecerdasan yang menurun ${ }^{[13]}$.

GAKY juga menjadi masalah pada anak usia prasekolah dan sekolah di banyak daerah di Indonesia. Hal ini sangat merugikan karena berhubungan erat dengan kehilangan point IQ atau tingkat kecerdasan anak. Upaya pemecahan langsung dalam menanggulangi GAKY, perlu dilakukan penyuluhan kesehatan secara berkala pada masyarakat, advokasi pada pembuat keputusan, serta pembingkatan pengetahuan kepada tenaga kesehatan ${ }^{[14]}$.

\section{KESIMPULAN}

Hasil penelitian yang dapat disimpulkan yaitu prestasi belajar siswa di SD Negeri 5 Kota Banda Aceh bisa disebabkan oleh asupan protein maupun penggunaan garam beryodium. Secara statistik, asupan protein berhubungan dengan prestasi belajar siswa, sedangkan penggunaan garam beryodium tidak berhubungan dengan prestasi belajar siswa SD Negeri 5 Kota Banda Aceh.

Selain itu dapat disarankan untuk memberikan bimbingan kepada pihak sekolah mengenai berbagai pengetahuan guna perkembangan kecerdasan anak untuk meningkatkan pengetahuan dan sikap sehingga kedepannya menjadi lebih baik lagi. Memberikan informasi kepada siswa, mengenai penggunaan garam beryodium yang bermanfaat untuk meningkatkan pertumbuhan fisik dan perkembangan kecerdasan bagi anak, adanya penyuluhan untuk menambah pengetahuan anak, bimbingan untuk merubah pola makan, dari pola makan yang tidak sehat, kearah yang lebih sehat. Serta, diharapkan kepada puskesmas (wilayah terdekat) agar lebih giat lagi melakukan penyuluhan dan pemeriksaan yodium dalam garam untuk meningkatkan pengetahuan dan sikap masyarakat sehingga kedepannya menjadi lebih baik lagi.

\section{DAFTAR PUSTAKA}

1. Hariyani, S.,2012. Gizi Untuk Kesehatan Ibu Dan Anak, Cetakan II. Penerbit Graha Ilmu, Yogyakarta.

2. George, S.M., 2012. Dasar - Dasar Pendidikan Anak Usia Dini, Cetakan I. Penerbit Indeks, Jakarta.

3. Muhibbin, S.,2013. Psikologi Pendidikan, Cetakan 18. Remaja Rosdakarya Offset, Bandung. 
4. Sari. 2011. Faktor-faktor Yang Berhubungan Dengan Penggunaan Garam Beryodium Di Rumah Tangga Di Kelurahan Ulak Karang Selatan Kota Padang Tahun 2011. Fakultas Kedokteran Universitas Andalas Padang

5. Andry.H., 2009. Gizi Kesehatan Masyarakat, Cetakan I. Buku kedokteran EGC, Jakarta.

6. Departemen Kesehatan Republik Indonesia,2010. Laporan Nasional Riset Kesehatan Dasar (RISKESDAS) Tahun 2010. Dapat diakses di www.riskesdas.litbang.go.iddownloadTabel Riskesdas2010.pdf (Diakses pada tanggal 8 februari 2014)

7. Departemen Kesehatan Republik Indonesia,2010. Laporan Nasional Dinas Kesehatan (DINKES) Tahun 2013. Dapat diakses www.dinkes.litbang.go.iddownloaddinkes20 $\underline{13 . p d f}$ (Diakses pada tanggal 9 februari 2014)

8. Mutalazimah, 2009. Status Yodium Dan Fungsi Kognitif Anak Sekolah Dasar Di SDN Kiyaran I Kecamatan Cangkringan Kabupaten Sleman, Fakultas Psikologi Universitas Muhammadiyah Surakarta.

9. Suryabrata., 2005. Psikologi Pendidikan, Cetakan 13, Raja Grafindo Persada, Jakarta.

10. Creswell, JW. Research Design: Pendekatan Kualitatif, Kuantitatif, dan Mixed. Editor: Ahmad Fawaid. Edisi Ketiga. Pustaka Pelajar. Yogyakarta. 2010.

11. Budiarto, E. Biostatistika Untuk Kedokteran dan Kesehatan Masyarakat. EGC. Jakarta. 2001.

12. Rahayu. A., 2007. Sumbangan Energi Dan Protein Makan Pagi Terhadap Angka Kecukupan Gizi Yang Dianjurkan (AKG) Berdasarkan Pola Asuh Anak, Jurnal Kesehatan Masyarakat Indonesia.

13. Merryana. A.,2013. Pengantar Gizi Masyarakat. Cetakan II. Kencana, Jakarta.

14. Hariyani, S.,2012. Gizi Untuk Kesehatan Ibu Dan Anak, Cetakan II. Penerbit Graha Ilmu, Yogyakarta. 